\title{
Teologi Politik: Politik Praktis Orang Percaya Menurut Roma 13:1-4
}

\author{
Yudhy Sanjaya, ${ }^{*}{ }^{1}$ Josanti, ${ }^{2}$ Aldrin Purnomo ${ }^{3}$ \\ Prodi Teologi, STT Real Batam \\ Prodi PAK, STT Real Batam \\ Prodi Teologi, STT Real Batam
}

\begin{abstract}
In theology, talking about politics is inevitable. Because the existence of believers cannot be separated from the life of the nation and state. Where the statement of faith cannot be separated from the presence and participation in the state order. This is demonstrated by one way of recognizing legitimate government. The Apostle Paul's letter in Romans 13: 1-4 affirms that the government is from God. The author uses the method of narrative interpretation approach to the text in Romans 13: 1-4 to get an understanding that there is a call that directs believers involved in practical politics. This paper will reveal what believers can do in showing their obedience to God through the practice of nation and state.
\end{abstract}

Keywords: Parenting, Family, Christianity, Growth, Faith

\begin{abstract}
Abstrak
Dalam berteologi, pembicaraan tentang politik adalah hal yang tidak bisa dihindari. Karena keberadaan orang percaya tidak bisa dilepaskan dari kehidupan berbangsa dan bernegara. Dimana pernyataan imannya tidak bisa dilepaskan dari kehadiran serta keikutsertaannya dalam bagian dari bernegara. Hal tersebut ditunjukkan dengan cara salah satunya mengakui pemerintahan yang legitimasi. Pernyataan Paulus dalam Roma 13:1-4 memberikan penegasan mengenai hal tersebut, bahwa pemerintahan berasal dari Allah. Penulis menggunakan metode pendekatan tafsir naratif atas teks dalam Roma 13:1-4 untuk mendapatkan pemahaman ada panggilan yang mengarahkan orang percaya terlibat dalam politik praktis. Tulisan ini akan mengungkapkan hal-hal apa saja yang dapat dilakukan orang percaya dalam menunjukkan ketaatannya pada Allah melalui praktek berbangsa dan bernegara.

Kata kunci : Teologi, Politik, Praktis, Orang Percaya
\end{abstract}

\section{PENDAHULUAN}

Pertumbuhan Dalam kehidupan berbangsa seperti di sebuah negara demokrasi Indonesia ini, sikap pengakuan terhadap pemerintahan yang ada melahirkan ketaatan. Sebagaimana yang disampaikan oleh Garner dalam buku nya Biblical Faith dikutip oleh Minggus Pranoto bahwa hal tersebut sabgat dipengaruhi oleh sikap gereja di Perjanjian Baru. Dimana pengaruh teologi Paulus dan Petrus perlu dimaknai dengan baru atau ditaruh dalam konsep yang baru. Atau dapat dikatakan bahwa, "In view of the rise and growth of democracy in many countries, the Pauline-Petrine doctrine of obedience to the governing authorities needs to be converted into new concepts which are more relevant to the existing 
relationship between the state and the people." Sikap penerimaan dan ketaatan yang tersebut yang mendorong gereja untuk membangun relasi pada negara dan bersikap partisipatif serta mengambil tanggung jawab agar gereja dapat menjalankan perannya dalam memberikan suara kenabian. Dengan demikian gereja menjadi aktif dan kreatif berfungsi sebagai 'garam dan terang' bagi pemerintahan di mana ia berada. Dengan pemikiran bahwa gereja hanya tunduk dan percaya saja bahwa negara sebagai hamba Allah. ${ }^{2}$ Menurut Fransiskus Irwan Widjaja, Sedikit sekali orang percaya yang dapat hidup untuk memelihara keseimbangan rohani, emosi dan moral mereka. Dalam tantangan tantangan dan perubahan-perubahan politik. ${ }^{3}$

Menurut Adolf Simamora salah satu topik yang juga menarik untuk dikaji adalah Teologi Politik Paulus tentang ketaatan terhadap Pemerintah. ${ }^{4}$ Pemikiran dan refleksi terhadap konsep politik Paulus dalam kitab Roma 13:1-4 menjadi pandangan politiknya. Dimana Paulus menempatkan posisi gereja terhubung dengan pemerintah atau negara. Hal senada disampaikan oleh Ni Nyoman bahwa gereja harus turut berproses dalam setiap kebijakan pemerintah. Gereja harus aktif mempengaruhi kebijakan negara melalui politik. Gereja tidak bisa menarik diri atau diam terhadap proses politik. ${ }^{5}$

\section{METODE}

Penulis menggunakan metode pendekatan tafsir naratif atas teks Surat Rasul Paulus dalam Roma 13:1-4 serta memperhatikan pandangan-pandangan ahli yang sudah ada sebelumnya.

\section{HASIL DAN PEMBAHASAN}

\section{Terminologi Politik}

Secara etimologi istilah politik dari berdasarkan bahasa Belanda yaitu politiek. Dan dalam bahasa Inggris politics, dimana kesemuanya dari berdasarkan bahasa Yunani yaitu

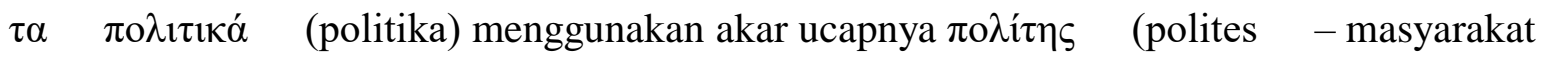
negara) \& $\pi$ ó $\lambda$ ı (polis - negara kota). Kata politik berkembang sebagai polites yg berarti warganegara, politeia yg berarti seluruh yg warga negara, politika yg berarti pemerintahan negara \& politikos yg berarti kewarganegaraan. ${ }^{6}$ Menurut Ronald Sianipar, Politik adalah

\footnotetext{
${ }^{1}$ Minggus Minarto Pranoto, "Relasi Gereja Dengan Negara," Amanat Agung 5 (2009).

2 Ibid.

${ }^{3}$ Fransiskus Irwan Widjaja, "Peran Gereja Terhadap Kehidupan Politik Di Wilayah Kepulauan Riau," Real Didache 1, no. 2 (2016): 117-140.

${ }^{4}$ Adolf Bastian Simamora, "Gereja Dalam Pusaran Politik Di Indonesia" (2019).

${ }^{5}$ Ni Nyoman Fransiska, "Entitas Gereja Dalam Berpolitik Di Indonesia (Tinjauan Sudut Etika Kristen)," Journal of Chemical Information and Modeling 53, no. 9 (2019): 1689-1699.

6 "Wikipedia," n.d.
} 
salah satu bidang pelayanan dalam kehidupan berbangsa dan bernegara, sama pentingnya dengan bidang-bidang kehidupan lainnya. ${ }^{7}$

Aristoteles (384-322 SM) sebagai orang pertama yang memperkenalkan kata zoon politikon, yang dapat doartikan sebagai pengamatannya tentang manusia. ${ }^{8}$ Melalui istilah itu, Ariestoteles menyatakan bahwa kehidupan sosial diidentikkan sebagai berpolitik dan berinteraksi antara dua orang atau lebih. Aristoteles melihat politik sebagai proses alami dan tidak dapat dihindari manusia.

Miriam Budiardjo berpendapat bahwa kata politik berasal dari kata polis yang artinya negara /kota. Kemudian pengertiannya berkembang menjadi polites (warga negara), politicos (kewarganegaraan), Civics, politiketechne (kemahiran berpolitik) dan politike pisteme (ilmu politik). Sedangkan dalam bahasaYunani adalah politea yang artinya the state of being a citizen, citizensip, the right or privilege of being a citizen, freedom of city ${ }^{9}$. Miriam Budiarjo yang mendefinisikan politik sebagai kegiatan atau aktivitas di suatu negara dalam menetapkan tujuan serta bagaimana cara pencapaian tujuan tersebut. ${ }^{10}$

\section{Latar belakang Pandangan Politik Paulus}

Pandangan politik Paulus dipengaruhi juga oleh latar belakang Paulus yang mana tulisannya adalah merupakan hasil pemikiran terhadap konsep politik Paulus. Paulus adalah keturunan Yahudi original, Tarsus, Sisilia tempat kelahiran Paulus merupakan pusat perniagaan internasional dan kota pelabuhan besar. Rabi Gamaliel adalah guru dari Paulus yang memberikan pendidikan keagamaan yahudi. Paulus merupakan warga Negara Roma, yang pada awalnya sangat tidak menyukai ajaran Kristus dan menentang penyebarannya dengan melakukan penangkapan serta penyiksaan pada umat Kristen. Namun pada akhirnya melalui peristiwa perjumpaan dengan Kristus membuatnya bertobat dan turut menyebarkan kekristenan.

Orang Yahudi melakukan pemberontakan sampai ke Palestina, terutama ke Galilea. Ada orang Zelot yang terus melakukan pertentangan pada permerintah Romawi saat itu. Mereka meyakini bahwa hanya Allah yang berkuasa dan tidak ada raja bagi orang-orang Yahudi. Menurut golongan ini hanya Allah yang bersedia menerima persembahan sehingga mereka tidak memberikan upeti. Mereka juga tidak puas dengan perlawanan pasif. Pemberontakan mereka bertujuan meniadakan pemerintahan sipil. Selain mereka melakukan terror terhadap pemerintah Romawi, mereka juga menteror sesama Yahudi yang membayar upeti pada pemerintah romawi. Paulus sangat tidak setuju dengan hal ini oleh karenanya Paulus memberikan pandangan teologis yang memisahkan kekristenan dari

\footnotetext{
${ }^{7}$ Ronald Sianipar, "Hubungan Partisipasi Umat Kristen Dalam Dunia Politik Dan Pendidikan Terhadap Mandat Amanat Agung," Real Didache 4, no. 1 (2019): 58-68.

${ }^{8} \mathrm{Ng}$ Philipus, Sosiologi Dan Politik, n.d. hal 89

${ }^{9}$ Miriam Budiadjo, Dasar-Dasar Ilmu Politik (Jakarta: Gramedia, 2008). Hal 13

${ }^{10}$ Ibid. hal. 90
} 
keberadaanpemberontakan Yudaisme. Paulus berpendapat bahwa orang kristenan bisa menjadi warga negara yang baik. ${ }^{11}$

\section{Hubungan Gereja dan Negara}

Gereja sudah semestinya terhubung dengan pemerintah atau negara. Pandangan ini disampaikan oleh Adolf Simamora yang didasarkan pada perryataan Karen L. Bloomquist. dkk, dalam bukunya Churches Holding Governments Accountable tentang relasi gereja dan pemerintah. Karen L.B. menyatakan ada tiga cara hubungan antara gereja dan pemerintah yang membawa kepada langkah yang salah. ${ }^{12}$

Pertama, Gereja dan pemerintah merupakan dua hal yang terpisah yang seharusnya tidak saling mempengaruhi satu sama lain. Tipe ini menggambarkan suatu pemisahan yang pasti antara keduanya: gereja berhubungan dengan hal-hal bersifat rohani sedangkan pemerintah dengan hal-hal yang bersifat jasmani. Ini barangkali disampaikan oleh seorang pietis yang melihat dunia sebagai yang jahat dan untuk dihindari sebisa mungkin. Iman adalah hubungan khusus pribadi dan tidak terkait dengan pemerintah. Tipe ini menekankan bahwa "Agama dan politik tidak bercampur". ${ }^{13}$

Kedua, gereja dikendalikan. Bisa dengan dengan cara paksaan ataupun kerelaan bekerjasama, gereja menjadi tunduk kepada pemerintah. Tahta dan altar menyatu dimana pimpinan negara dan Pimpinan Tertinggi Gereja berjalan bergandengan tangan. Dalam tipe ini, dukungan yang gereja berikan kepada pemerintah tanpa syarat. ${ }^{14}$

Ketiga, pemerintah di kendalikan gereja. Dimana pemerintah diperlakukan dalam kendali kekuatan agama. Dalam tipe ini, otoritas rohani mendominasi kekuasaan yang dimiliki pemerintah. ${ }^{15}$

\section{Teokrasi: Pemerintah berasal dari Allah}

Pada zaman Perjanjian Lama, tepatnya zaman Nabi Musa, kerajaan bangsa Israel merupakan berbentuk teokrasi, yg merupakan Allah yg memerintah atas bangsa Israel. Walaupun Musa, Harun \& Yosua bertindak menjadi pemimpin umat Israel keluar menurut tanah Mesir menuju tanah Kanaan. Tetapi, mereka seluruh bertindak hanya seturut menggunakan perintah menurut Allah. Bentuk pemerintahan yg teokrasi menerima tanggapan dan protes menurut umat Israel sendiri dalam masa Hakim Samuel, dimana mereka sangat menginginkan seseorang raja misalnya bangsa-bangsa lain yg sudah memiliki raja terlebih dahulu. Keinginan tersebut terwujud atas diri Saul yang

\footnotetext{
${ }^{11}$ Marcus Borg, A New Context for Romans XIII," New Testament Studies (Michigan: W. B. Eerdmans Publishing Company, 1976). Hal 205-218

12 Simamora, "Gereja Dalam Pusaran Politik Di Indonesia."

13 Ibid.

${ }^{14}$ Ibid.

15 Ibid.
} 
menjadi Raja pertama bagi umat Israel. Daud dan Salomo menjadi raja ke dua dan ketiga. Dan setelah pemerintahan Raja Salomo kerajaan Israel terpecah menjadi dua, yaitu Kerajaan Israel Utara dan kerajaan Israel Selatan. Semakin terlihatlah kehancuran bangsa Israel selesainya kerajaan berbentuk teokrasi ditinggalkan dan berubah sebagai Monarki. ${ }^{16}$

Paulus mempunyai pandangan teologis bahwa sistem politik pemerintah yang ada adalah teokrasi. Paulus menyatakan dengan sangat jelas bahwa otoritas dan kekuasaan pemerintahan berasal dari Allah sebagaimana yang dituliskan dalam suratnya pada jemaat di Roma, yaitu di Roma 13:1.17

Paulus memberikan Pandangan Teologis berupa pemahaman yang positif terhadap pemerintah yang mengungkapkan ada peran serta Tuhan di dalamnya. Pemahaman yang mau diberikan kepada jemaat bahwa Allah yang disembah adalah Allah yang Maha Kuasa. Segala kuasa yang ada di bumi adalah milik Allah. Ia adalah Penguasa tertinggi, di mana kewenangan yang dimiliki Nya melebihi segalanya. Termasuk penguasa-penguasa yang ada di bumi. Pemerintah sebagai penguasa suatu wilayah terotorial hanya akan mendapatkan legitimasi atau pengakuan bila Allah yang memberikan. Ini yang disebut dengan Teokrasi dimana kedaulatan adalah tetap menjadi milik Allah.

Sedangkan dalam Roma 13:2, Paulus menyatakan bahwa respon atas hal tersebut diharapkan adanya kepatuhan jemaat pada pemerintah yang legitimasi. ${ }^{18}$. Paulus menempatkan pemerintah sebagai representasi otoritas Allah. Sehingga hukuman diberlakukan bagi setiap orang yang melawan pemerintah. Ada keterikatan yang melekat antara Allah dan pemerintah, sehingga yang melawan pemerintah dianggap melawan Allah.

Noh Ibrahim menegaskan dalam tulisannya bahwa Paulus mempunyai pandangan kehadiran pemerintah sebagai alat ilahi yang memyelamatkan dunia dari kekacauan. Bila kekaisaran disingkirkan maka ada kemungkinan dunia akan terpecah-belah. Dalam kondisi yang ideal yang mestinya terjadi pemerintah dapat menjadi perekat orang-orang dalam kesatuan kasih. Paulus melihatpemerintah sebagai suatu alat di tangan Allah untuk menjaga dunia dari kekacauan. ${ }^{19}$

Karena sesungguhnya kehadiran Pemerintah adalah membuat keteraturan dan perdamaian bagi setiap orang yang berada dalam wilayah kekuasaannya sebagaimana tujuan dari politik itu sendiri yang sepadan dengan tujuan awal Allah pada kehidupan manusia. Upaya-upaya yang dilakukan pemerintah untuk hal tersebut harus mendapatkan dukungan dari rakyatnya. Melalui undang-undang, peraturan ketentuan dan tata tertib pemerintah menjalankan tugas dan fungsi sesuai dengan tanggung jawab yang diamanahkan kepadanya.

\footnotetext{
${ }^{16}$ S. Wismoady Wahono, Disini Kutemukan (Jakarta: BPK Gunung Mulia, 2004). Hal 81-84

${ }^{17}$ Alkitab Edisi Studi (Bogor: Lembaga Alkitab Indonesia, 2011). Hal 1858

18 ibid

${ }^{19}$ Noh Ibrahim Boiliu, "Etika Teologi Politik: Analisis Etis Teologis Ketaatan Kepada Pemerintah," Journal of Chemical Information and Modeling 8, no. 9 (2017): 1-58.
} 
Meskipun dalam prakteknya pembentukan suatu pemerintah bisa saja melalui proses pemilihan yang berdasarkan demokrasi, tapi tetap peran serta Allah dalam proses pemilihan tersebut tidaklah diabaikan. Ada ungkapan latin yang berkata : 'vox populi, vox dei', yang artinya suara rakyat merupakan suara Tuhan. Ungkapan ini menyatakan bahwa suara rakyat tidak bisa diabaikan dan harus dihargai karena suara rakyat tesebut bisa menjadi sarana penyampaian kehendak Allah. Ataupun dapat juga pemerintahan secara monarki. Tapi tetap diyakini ada peran serta Allah dalam penunjukkan siapa yang akan menjadi raja. Hal ini ditunjukkan dalam peristiwa penunjukkan Daud sebagai raja menggantikan Saul.

\section{Pemerintah sebagai hamba Allah}

Pemerintah sebagai hamba Allah. Jadi bila para pemimpin suatu negara/pemerintahan menempatkan diri sebagai hamba, maka tentunya tugas yang ada dilakukan dengan bertanggung jawab. Hal ini dituliskan dalam Roma 13:4, yang menyatakan bahwa keberadaan pemerintah sebagai hamba Allah demi kebaikanmu. Kata "hamba" di sini ditulis dalam bahasa aslinya diakonos yang mempunyai pengertian yang berbeda dengan kata doulos. Meskipun kedua kata tersebut biasanya diterjemahkan dengan pelayan atau hamba. Doulos lebih mempunyai konotasi ke suatu status sosial paling rendah, status sebagai budak, milik orang lain sebagai tuannya. Sedangkan diakonos punya konotasi ke fungsi atau peran sebagai hamba atau pelayan. ${ }^{20}$

Paulus dalam tulisannya menyatakan tentang kuasa-kuasa lain yang melakukan kejahatan sebagai latar belakang pandangan tentang keselamatan manusia. Ungkapan Paulus yang paling khas ialah "penguasa-penguasa" (exousia), "pemerintah-pemerintah dan kuasa-kuasa" (arkhai dan dunameis), dan "penguasa-penguasa dunia" (kosmokratores). Dari pemahaman tersebut perlu supaya mendapatkan pengertian yang benar perihal pengajaran Paulus terhadap hal-hal yang berhubungan dengan pemerintahan. Dia menyebutkan bahwa pemerintah-pemerintah dan kuasa-kuasa dalam daftar mengenai hal-hal yang tidak dapat memisahkan manusia dari kasih Allah (Roma. 8:38-39). Kristus jauh lebih tinggi daripada segala pemerintah dan penguasa (Ef. 1:21).

Nasehat dalam Roma 13:1 dan Titus 3:1 agar takluk kepada pemerintah menggunakan kata yang sama dan hal ini memperlihatkan bahwa dalam pemikiran Paulus terdapat hubungan yang erat antara pemerintah dan kuasa-kuasa rohani yang menyebabkan pemerintah itu sering disebutnya sebagai hamba Allah yang menyampaikan kehendak Allah akan dunia ini. ${ }^{21}$

\section{Partisipasif : Turut terlibat aktif}

\footnotetext{
${ }^{20}$ Paskalis Edwin and I Nyoman Paska, “Haruskah Kita Takluk Kepada Pemerintah?” (n.d.): 1-7.

${ }^{21}$ Donald Guthrie, Teologi Perjanjian Baru I (Jakarta: BPK Gunung Mulia, 2008). Hal 136-137
} 
Pada masa Paulus, Orang Kristen di Roma berada dalam masa penghambaan, yang dilakukan oleh kekaisaran Romawi. Penindasan membuat umat sangat mengharapkan kedatangan Yesus Kedua. Di sini Paulus hendak mengembalikan warga jemaat untuk mewujudkan suatu pola kehidupan praktis orang Kristen, termasuk praktis berpolitik. Paulus menegaskan bahwa saat orang Kristen menantikan kedatangan Yesus bukan berarti tidak peduli dengan dunia ini. Malah sebaliknya jemaat harus tetap memberikan perhatian kepada dunia termasuk keikutsesrtaan dalam politik.

Kerinduan Paulus tersebut ditunjukkan dalam tulisannya di Roma 13:6-7 yang berbunyi menyatakan alasan mengapa mesti membayar pajak. Karena pemerintah diposisikan sebagai pelayan-pelayan Allah. ${ }^{22}$ Membayar pajak adalah bagian praktek politik yang menyatakan kesediannya mengambil tanggung jawab sebagai bagian yang tidak terpisahkan dari kekuasaan. Jemaat dapat menempatkan diri dan dapat merespon secara tepat.

Bentuk ketaatan pada pemerintah adalah kesediaan ikut serta dalam kewajiban yang memang seharusnya dilakukan. Membayar pajak bukan satu-satunya kewajiban yang harus dilakukan, masih banyak bentuk lain yang harus dilakukan dimana itu merupakan keterlibatan secara aktif. Bahkan tidak menutup kemungkinan terlibat secara praktis dalam pemerintahan yaitu memberikan dirinya untuk terlibat langsung menjadi pelaku di pemerintahan. Mengambil peran sebagai pemegang kekuasaan dalam pengambil keputusan dan serta kebijakan.

Pada masa Paulus saat itu ada orang-orang Yahudi yang mempunyai hak khusus dilibatkan oleh pemerintah romawi dalam menjalankan roda pemerintahan. Baik mereka sebagai 'penguasa-penguasa kecil', prajurit, pemungut cukai.

\section{KESIMPULAN}

Pemerintahan bukan sesuatu yang buruk bila dipahami sebagai anugerah Allah. Dimana kekuasan yang ada berasal dari Allah dan bertujuan untuk mendatangkan kebaikan bagi masyarakat. Jabatan dan kekuasaan itu dipandang sebagai kesempatan untuk mengabdi kepada kepada Tuhan. Setiap orang Kristen semestinya tunduk kepada pemerintah karena pemerintah merupakan hamba Allah. Pemahaman bahwa pemerintahan itu ada karena ketetapan Allah dan mereka menjadi hamba Allah untuk menjalankan roda kepemimpinan yang ada di dunia.

Orang yang percaya kepada Allah melihat keterlibatan dalam politik praktis sebagai bentuk pelayanan kepada Allah. Adanya panggilan sebagai politikus Kristen dimana menempatkan dirinya dipakai Allah sebagai penerima kekuasaan. Kehadirannya di pemerintahan untuk mewujudkan kerinduan Allah dalam menyatakan Injil.

\section{KEPUSTAKAAN}

${ }^{22}$ Ibid hal 1859 
Boiliu, Noh Ibrahim. "Etika Teologi Politik: Analisis Etis Teologis Ketaatan Kepada Pemerintah." Journal of Chemical Information and Modeling 8, no. 9 (2017): 1-58.

Budiadjo, Miriam. Dasar-Dasar Ilmu Politik. Jakarta: Gramedia, 2008.

Edwin, Paskalis, and I Nyoman Paska. "Haruskah Kita Takluk Kepada Pemerintah?" (n.d.): $1-7$.

Fransiska, Ni Nyoman. "Entitas Gereja Dalam Berpolitik Di Indonesia (Tinjauan Sudut Etika Kristen).” Journal of Chemical Information and Modeling 53, no. 9 (2019): 1689-1699.

Guthrie, Donald. Teologi Perjanjian Baru I. Jakarta: BPK Gunung Mulia, 2008.

Marcus Borg. A New Context for Romans XIII," New Testament Studies. Michigan: W. B. Eerdmans Publishing Company, 1976.

Philipus, Ng. Sosiologi Dan Politik, n.d.

Pranoto, Minggus Minarto. "Relasi Gereja Dengan Negara." Amanat Agung 5 (2009).

Sianipar, Ronald. "Hubungan Partisipasi Umat Kristen Dalam Dunia Politik Dan

Pendidikan Terhadap Mandat Amanat Agung." Real Didache 4, no. 1 (2019): 58-68.

Simamora, Adolf Bastian. "Gereja Dalam Pusaran Politik Di Indonesia" (2019).

Wahono, S. Wismoady. Disini Kutemukan. Jakarta: BPK Gunung Mulia, 2004.

Widjaja, Fransiskus Irwan. "Peran Gereja Terhadap Kehidupan Politik Di Wilayah Kepulauan Riau." Real Didache 1, no. 2 (2016): 117-140.

Alkitab Edisi Studi. Bogor: Lembaga Alkitab Indonesia, 2011.

"Wikipedia," n.d. 